\title{
Letter to the Editor: White Cell Ornithine Transcarbamylase Activity Cannot Detect the Liver Enzyme Deficiency
}

\author{
PHILIP J. SNODGRASS, REBECCA S. WAPPNER, AND IRA K. BRANDT
}

Departments of Medicine and Pediatrics, Indiana University School of Medicine, Indianapolis, Indiana, USA

We have been unable to confirm the report of Wolfe and Gatfield (3) that assay of ornithine transcarbamylase (OTC) in leukocytes can substitute for assay of this enzyme in a liver biopsy in order to make a diagnosis of ornithine transcarbamylase deficiency.

Leukocytes were prepared from $40 \mathrm{ml}$ blood as follows: red cells were settled in Plasmagel (HTI Corp., Buffalo, NY), the plasma and white cells aspirated and the white cells centrifuged to form a pellet. The white cells were washed first with isotonic $\mathrm{NaCl}$, then for $45 \mathrm{sec}$ in distilled water to lyse red cells, and finally three times in $0.05 \mathrm{M} \mathrm{NaCl}$. The centrifuged leukocyte pellet was frozen at
I shows that urea cycle enzyme activities in the liver homogenates were within or close to the normal range except for OTC, which was $10 \%, 6 \%$, and $13 \%$, respectively, of the appropriate normal mean values (3). The white cell OTC activities bore no relationship to the liver deficiencies, being $1500 \%, 98 \%$ and $1700 \%$ of the control mean value. One patient (S.B.) also had elevated values for carbamly phosphate synthetase and argininosuccinate lyase, while one (A.H.) had low values for argininosuccinate synthetase and lyase.

These results lead us to conclude that ornithine transcarbamylase deficiency in liver cannot be inferred from the results of this

Table 1. Urea cycle enzymes ${ }^{a}$

v

\begin{tabular}{|c|c|c|c|c|c|c|}
\hline \multirow[b]{2}{*}{ Tissue and Patient } & \multirow[b]{2}{*}{ Protein $(\mathrm{mg} / \mathrm{g})^{b}$} & \multicolumn{5}{|c|}{ Units/mg protein ${ }^{b}$} \\
\hline & & CPS & OTC & AS & $\mathrm{AL}$ & Ase \\
\hline \multicolumn{7}{|l|}{ Liver, needle biopsy } \\
\hline A.H. & 149 & 0.81 & 3.63 & 0.36 & 0.89 & 295 \\
\hline Controls, mean ${ }^{3}$ & 169 & 1.63 & 34.6 & 0.33 & 1.00 & 274 \\
\hline Controls, SD & 20 & 0.42 & 4.2 & 0.10 & 0.18 & 64 \\
\hline \multicolumn{7}{|l|}{ Liver, wedge biopsy } \\
\hline A.W. & 90 & 2.44 & 2.72 & 0.57 & 1.83 & 569 \\
\hline S.B. & 122 & 1.24 & 5.91 & 0.26 & 1.28 & 431 \\
\hline Controls, mean ${ }^{3}$ & 145 & 1.91 & 44.2 & 0.62 & 1.49 & 579 \\
\hline \multirow[t]{2}{*}{ Controls, SD } & 20 & 0.27 & 7.7 & 0.14 & 0.26 & 106 \\
\hline & Protein $(\mathrm{mg} / \mathrm{ml})^{b}$ & & & & & \\
\hline \multicolumn{7}{|l|}{ Leukocytes, frozen } \\
\hline A.H. & 5.88 & 0.009 & 0.971 & 0.054 & 0.068 & 11.9 \\
\hline A.W. & 2.88 & 0.008 & 0.062 & 0.486 & 0.326 & 10.2 \\
\hline S.B. & 1.37 & 0.097 & 1.080 & 0.278 & 0.759 & 25.1 \\
\hline Controls (14), mean & 6.50 & 0.003 & 0.063 & 0.331 & 0.232 & 22.5 \\
\hline Controls, SD & 1.31 & 0.003 & 0.093 & 0.118 & 0.076 & 12.2 \\
\hline Controls, range, $\mathrm{min}$ & & 0.000 & 0.002 & 0.181 & 0.154 & 7.6 \\
\hline Controls, range, $\max$ & & 0.009 & 0.345 & 0.535 & 0.398 & 46.7 \\
\hline
\end{tabular}

${ }^{a}$ CPA: carbamyl phosphate synthetase; OTC: ornithine transcarbamylase; AS: argininosuccinic acid synthetase; AL: argininosuccinic acid lyase; Ase: arginase.

${ }^{b}$ One unit equals $1 \mu \mathrm{mol}$ product formed/hr; liver protein is milligrams per $\mathrm{g}$ wet $\mathrm{wt}$; leukocyte protein is milligrams per ml of cell homogenate.

$-60^{\circ}$ for less than 3 days, thawed, $1.4 \mathrm{ml}$ of distilled water added, frozen and thawed three times and the cell suspension was homogenized with a Polytron tissue homogenizer for $15 \mathrm{sec}$. The urea cycle enzymes were assayed under conditions optimal for the human enzymes (1). OTC and carbamyl phosphate synthetase assays contained $0.1 \mathrm{ml}$ of undiluted homogenate in the $0.3 \mathrm{ml}$ assay mixture and were incubated for $1 \mathrm{hr}$ at $37^{\circ}$. Table 1 shows the normal values obtained on 14 healthy adults. No differences were noted between fresh or frozen white cell pellets. The range of normal values is very wide for OTC, and carbamyl phosphate synthetase activity is almost undetectable.

Three female patients with the typical clinical syndrome of OTC deficiency and with hyperammonemia during febrile illnesses or unrestricted ingestion of protein underwent biopsies of the liver, which were frozen at $-60^{\circ}$ and assayed within 3 days. White cells were prepared as above and assayed in 3 days. Table enzyme's activity in peripheral leukocytes, but that liver biopsy is still necessary to confirm the diagnosis. Further correlations are necessary to conclude that liver deficiencies of the other enzymes can be detected in leukocytes.

\section{REFERENCES}

1. Nuzum. C. T.. and Snodgrass. P. J.: Multiple assays of the five urea-cycle enzymes in human liver homogenates. In: S. Grisolia, R. Baguena, and F. Mayor: The Urea Cycle, Chap. 21, pp. 325-349 (John Wiley \& Sons, New York, 1976).

2. Snodgrass, P. J., and DeLong, G. R.: Urea-cycle enzyme deficiencies and an increased nitrogen load producing hyperammonemia in Reye's syndrome. New Engl. J. Med., 294: 855 (1976).

3. Wolfe. D. M., and Gatfield, P. D.: Leukocyte urea cycle enzymes in hyperammonemia. Pediat. Res., 9: 531 (1975).

Note: A rebuttal to this letter will be forthcoming from $D$. M. Wolfe. 